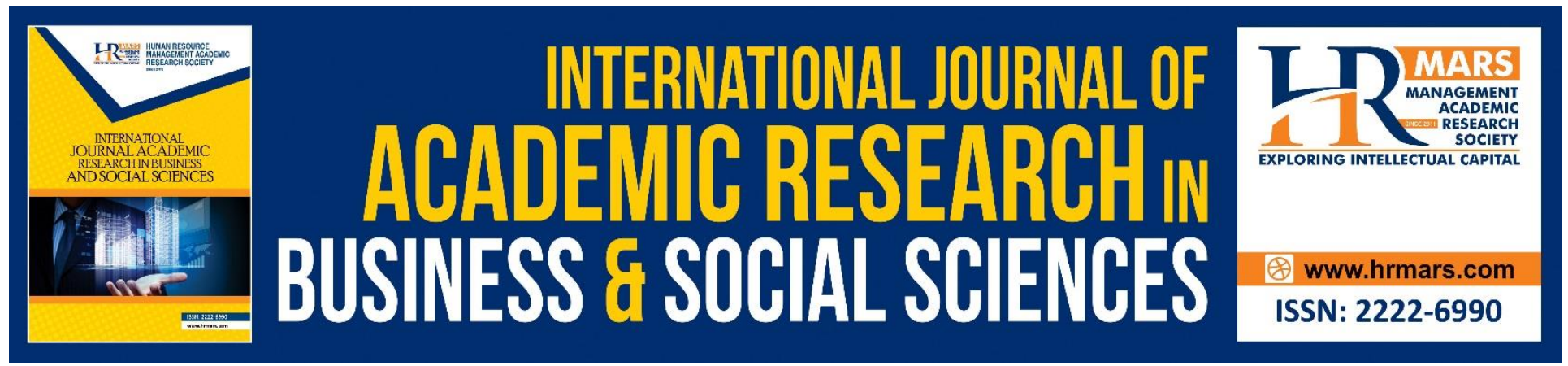

\title{
Investigating the Effect of Non -Financial Rewards on Staff Productivity in Shoprite Company, Enugu
}

Orga, Christopher Chukwudi, Mbah, Paulinus Chigozie, Ekechukwu Chijioke

To Link this Article: http://dx.doi.org/10.6007/IJARBSS/v8-i9/4669

DOI: $\quad 10.6007 /$ IJARBSS/v8-i9/4669

Received: 12 August 2018, Revised: 03 Sept 2018, Accepted: 29 Sept 2018

Published Online: 15 October 2018

In-Text Citation: (Orga, Mbah, \& Chijioke, 2018)

To Cite this Article: Orga, C. C., Mbah, P. C., \& Chijioke, E. (2018). Investigating the Effect of Non -Financial Rewards on Staff Productivity in Shoprite Company, Enugu. International Journal of Academic Research in Business and Social Sciences, 8(9), 950-964.

Copyright: (C) 2018 The Author(s)

Published by Human Resource Management Academic Research Society (www.hrmars.com)

This article is published under the Creative Commons Attribution (CC BY 4.0) license. Anyone may reproduce, distribute, translate and create derivative works of this article (for both commercial and non-commercial purposes), subject to full attribution to the original publication and authors. The full terms of this license may be seen

at: http://creativecommons.org/licences/by/4.0/legalcode

Vol. 8, No. 9, September 2018, Pg. 950 - 964

http://hrmars.com/index.php/pages/detail/IJARBSS

JOURNAL HOMEPAGE

Full Terms \& Conditions of access and use can be found at http://hrmars.com/index.php/pages/detail/publication-ethics 


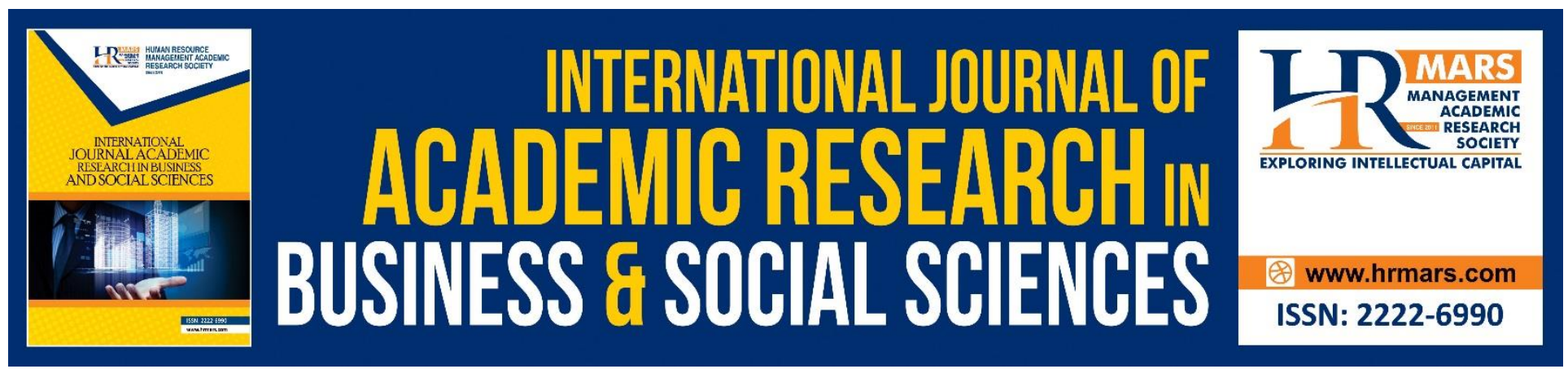

\title{
Investigating the Effect of Non -Financial Rewards on Staff Productivity in Shoprite Company, Enugu
}

\author{
Orga, Christopher Chukwudi (Ph.D) \\ Department of Business Administration, Faculty of Management Sciences, Enugu State University of \\ Science and Technology (ESUT), Enugu State, Nigeria. \\ Email: chrisorga@yahoo.com
}

Mbah, Paulinus Chigozie

Department of Business Administration, Faculty of Management Sciences, Enugu State University of Science and Technology (ESUT), Enugu State, Nigeria.

\section{Ekechukwu Chijioke}

Department of Banking \& Finance, Faculty of Management Sciences, Enugu State University of Science and Technology (ESUT), Enugu State, Nigeria.

\begin{abstract}
The study examined the effect of non -financial rewards on staff productivity in Shoprite Company Enugu. The study sought to determine the relationship between medical benefits and level of absenteeism; the relationship between having relaxation areas and volume of output. Relevant research questions were asked, and hypotheses were formulated and tested. Primary and secondary data were used. The primary sources were the administration of a questionnaire to the staff of Shoprite. The population of 275 was used. Copies of the questionnaire were administered and were returned. Two hypotheses were tested using F-statistic. It was found that the relationship between medical benefits and the level of absenteeism was significantly high, hence F(95, $n=275)=1046.270$. The relationship between having relaxation areas and volume of output was significantly high, hence $F(95, n=275)=1345.096, p<0.05$. It was concluded that non-financial reward impacted on staff productivity, and commitment to the task. It was recommended amongst others that organizations should offer the proper medical facility to its employees to keep them motivated.
\end{abstract}

Keywords: Non-financial, rewards, Staff, productivity.

Introduction

Non-financial reward and staff motivation have always been a major problem for many organizations (Neelam, Uzma, \& Almas, 2013). This has been regarded as the very important issue that many 
organizations are looking forward to ensuring it succeeds. The staff member has to be retained in an organization because of various reasons. They include: long sewing employees in an organization gain experience and thus improve on their efficiency, costs of training and workshops are reduced, time wastage is minimized because of employees' experience. This has made it imperative for the management of an organization to guarantee that employees are retained, and the turnover is reduced (Josephine, 2015).

So it is evident that financial reward is important in the motivation of executives, but it is not the only incentive used to achieve maximum results. So if the rewards are attractive and linked to performance people are motivated to take action. The intended effort is expected to turn into actual effort when people believe their hard work will result in a good reward.

Management recognizes motivation as a major responsibility. Our view of motivation is that it is anything that stimulates people to act or achieve in a better way any stated objective. Motivation is not just restricted to physical or tangible things like money but extends to intangible things such as psychological factors. What motivates is also affected by the situation, the inner drives, the needs, and objectives or goals of people. Those things we bring into a work situation that make people work to the best of their ability can be classified as motivational tools. There are certain needs and urges that make them behave the way they do. Motivational studies are concerned with these drives and urges. Employers are very intimately involved with this subject. Money is no longer the exclusive motivator it was formerly believed to be (Ezewuzie, 2008).

In addition to financial rewards, the job itself must be appealing for the individual to make up a type of reward. One has to get the satisfaction that the job itself is good enough for him or her. Many still ignore that fact that no organization can survive without its workers, and the workers themselves cannot be productive if their needs are not met. Nnadi (2010) posits that managers motivate employees for them to put in their best in the production process and the attainment of organizational goals adding that employees are motivated according to their commitment to the organization. Managers of an organization motivate their workers to enable them to exhibit their potential skills and ability effectively for the achievement of the organizational goal and some of the things they do to motivate their workforce is by providing their psychological, social, love, esteem and self-actualization needs (Eboh, 2013).

Other non-monetary incentives such as price, job promotion, upgrading and advancement, job security and recognition may go a long way to advance the confidence of workers. If workers needs are satisfied, it might lead to an increase in output. Nevertheless, every manager regardless of the size of the organization can incorporate motivation into the environment to stimulate and influence employee. Based on the above, therefore the study investigated nonfinancial rewards and staff productivity.

\section{Statement of the Problem}

Financial rewards can be utilized depending on the capability of the organizations or employers to pay. At times, the money is not paid leading to some of the workers leaving for greener pastures. These external factors impact the viability of the organization, and they can be reduced by less costly, convenient and long-term non-financial rewards which include job flexibility, expressions, like "well 
done," medical care, organizing parties, providing relaxation areas, etc. to reinforce good behaviour and productivity. Not only financial rewards are the key to employee retention.

The motivation of employees in the organization, in Nigeria, is overwhelmed with a myriad of unethical practices. These unethical practices include bias when motivating employees, discrimination, and favouritism. In many organizations, management motivates rewards, develops and trains their employees and these lead to improved productivity of the worker.

Challenges often arise either because those assigned to handle this responsibility are corrupt or may neglect to handle it appropriately. Besides, many human resource managers do not posess the adequate human relations skills necessary to handle such a sensitive responsibility.

If employee motivation is not given a serious attention, it might suppress creativity; lead to low productivity, and absenteeism and the organization might have low competitive advantage. All these might culminate in low staff productivity and invariably poor organizational performance. Hence, the study on the effect of non -financial rewards and staff productivity has become imperative, with Shoprite Enugu as the case organization.

\section{Objectives of the Study}

The general objective of the study was to investigate the effect of non-financial reward on the productivity of the staff of Shoprite. The specific objectives were to:

i. Examine the effect of medical benefits on the level of absenteeism of staff of Shoprite, Enugu.

ii. Assess the effect of the provision of relaxation areas on the volume of output of staff of Shoprite, Enugu.

\section{Research Questions}

The following questions were answered in the study:

i. What is the effect of medical benefits on absenteeism of staff of Shoprite Enugu?

ii. What is the effect of the provision of relaxation areas on the volume of output of staff of Shoprite Enugu?

\section{Research Hypotheses}

The following hypotheses were formulated for the study:

i There is positive effect of medical benefits on level of absenteeism of staff of Shoprite Enugu. ii. There is a positive effect of provision of relaxation areas on volume of output of staff of Shoprite Enugu.

\section{Review of Related Literature Conceptual Framework Non-financial Reward}

This is compensation given in a transaction which does not involve cash. A non-monetary reward can consist of almost any material object such as jewelry, precious metals or an automobile for example. 
In business, a non-monetary reward can also be a service such as improvements made on a property or repairs done on a car (Business Dictionary, 2018).

In employment, it is a reward to an employee other than extra pay. Many non-financial rewards are bonuses such as company cars, free private medical care, and free pension entitlement. However, an employee may be rewarded, for example, by being given a better office or a bigger budget to control, or by being given the choice of where to take a posting in a company. Non-financial rewards can be very cost effective for companies because, in contrast with a pay increase, little or no income tax or national insurance contributions are paid.

Non-financial incentive programmes and reward programmes structured to motivate positive behaviour change through means other than money motivate and retain employees; a motivated employee will achieve a great deal. A demotivated employee will be slow, horizontal to error and not likely to achieve. Non-financial reward helps to build feelings of confidence and satisfaction in employees and can be very important for their long-term effect (Armstrong, \& Brown, 2016).

\section{Concept of Productivity}

Productivity describes various measures of the efficiency of production. A productivity measure is expressed as the ratio of output to inputs used in a production process, i.e., output per unit of input. Productivity is a crucial factor in the production performance of firms and nations. Increasing national productivity can raise living standards because more real income improves people's ability to purchase goods and services, enjoy leisure, improve housing and education and make businesses to be more profitable. There are many different definitions of output, and the choice among them depends on the purpose of the productivity measurement and/or data availability (Abramovitz, 2016).

\section{Theoretical Framework of the Study}

Abraham Maslow's Hierarchy of Needs Theory guided the study.

\section{Abraham Maslow's Hierarchy of Needs Theory}

Money may be a motivator but not for all workers. This was supported by Maslow"s theory of the hierarchy of needs. Maslow (1954) suggests a hierarchy of five needs that exists; basic (physiological needs), love (social needs), security needs, self-esteem and self-actualization or fulfillment. Abraham Maslow based his theory of human needs on creative people who used all their talents, potential, and capabilities (Bootzin, Loftus, Zajonc, Hall, 1983). His methodology differed from other psychological researchers who mostly observed mentally unhealthy people. Maslow (1943) felt that human needs were arranged in a hierarchical order that could be divided into two major groups: for basic needs are physiological, such as food, water, and rest; and psychological, such as warmheartedness, security, and self-esteem. These basic needs are also called "inadequacy needs" because if an individual does not meet them, then that individual will strive to make up for the deficiency.

Meta needs. These include justice, kindness, beauty, order, harmony, etc. Basic needs normally take priority over these meta needs. For example, an individual who lacks food or water will usually not 
listen to justice or beauty needs. These needs are often listed in a hierarchical order in the form of a pyramid to show that the basic needs (bottom ones) must be met before the higher order wants. It should be noted that approximately no one stays in one particular hierarchy for an extended period. We constantly strive to move up, while at the same time various forces outside our control try to push us down. Those on top get pushed down for short time periods, e.g., the demise of a loved-one or a plan that did not work; while those on the bottom get pushed up, e.g., earn the education they need or come crossways a small reward or prize. Our goal as leaders, therefore, is to help people obtain the skills, knowledge, and benefits that will push them up the hierarchy. Maslow's theory postulates that people who had their basic needs met were expected to become much improved workers as they are able to concentrate on rewarding the organization's visions, rather than consistently struggling to make ends meet.

\section{Empirical Review}

Anderson \& Geldenhuys (2011) carried out an investigation into the relationship between absenteeism and employer-sponsored child care. Given the high loss of returns due to absenteeism, exploring different ways of managing absenteeism in South African companies, such as familyfriendly practices, had become important. Establishing onsite employer-sponsored child-care facilities is an example of such practices. The purpose of the article was, initially, to report on exploratory research that was done to study the relationship between absenteeism and on-site employer-sponsored child care. The following dimensions of malingering were examined over a period of one year: absence frequency, absence severity, attitudinal absence and medical absence. The results of two companies, one with a facility and one without a facility, were then compared in order to establish the relationship between absenteeism and an on-site facility. Secondly, this article also reported on the relationship between demographic variables and absenteeism. The outcome indicated a significant negative relationship between on-site employer-sponsored child care and absenteeism. Regarding the influence of demographical variables, significant differences were found with respect to absenteeism-based marital status and age, while no significant difference was found with respect to absenteeism based on gender and race. That made a specific contribution to studies on the use of on-site employer-sponsored child-care facilities for managing absenteeism, specifically in the South African context, and also sheds new light on the influence of demographical variables on absenteeism.

Ren and Thomas (2013) studied firms' sickness costs and workers' sickness absences. In many countries, social security insured firms against their workers' sickness absences. The insurance might create a moral hazard for firms, leading to inefficient monitoring of absences or to underinvestment in the prevention of absences. They exploited an administrative threshold in the Austrian social security that defined whether a firm had to pay a deductible for its blue-collar worker's sicknesses or not. The quasi-experimental state of affairs around the threshold provided causal evidence on the extent of moral hazard induced by the deductible. They applied a regression discontinuity design to estimate the differences in the incidences and durations of sicknesses for firms that faced the deductible and those who did not. They found that the deductible did not lead to different sickness 
INTERNATIONAL JOURNAL OF ACADEMIC RESEARCH IN BUSINESS AND SOCIAL SCIENCES Vol. 8, No. 9, Sept. 2018, E-ISSN: 2222-6990 @ 2018 HRMARS

outcomes and concluded that relatively low deductibles had little impact on firms' management of sicknesses.

Syukra (2014) examined the relationship between training, compensation and employment promotion with labour productivity of employees in the public health centre. The study found that the gap between the labour productivity of developed and developing countries was different. Indonesia had a number of output gap ratio of labour. Productivity in 2010 was 65.7 percent compared to 75.2 percent of China's. In the province of West Sumatra, the ratio of labour productivity in different types of health workers and health-care institutions in 2010 averaged only 53.2 percent. The aim of the study was to determine the relationship between training, compensation, employment promotion with labour productivity employees in Public Health Centre of BukittinggiWest Sumatera. The research design used in the study was descriptive and analytical with a crosssectional study, the study population was both government employees at public health centre, and honourary civil servants who were still active and the samples were taken in total sampling. The independent variables in the study were training, compensation, employee promotion, and the dependent variable was labour productivity. The research instrument used in the research was a questionnaire to determine the relationship between training, compensation, and employment promotion with labour productivity employees in Public Health Centre of Bukittinggi-West Sumatra and the data analysis was bivariate analysis using the Chi-Square test and the degree of confidence (CI) 95 percent $(\mathrm{O}=0.05$ ). The study found the employees who agreed with a good training increased work capacity by 21 (67.7 percent), employees who claimed compensation received had fulfilled expectations by 17 (54.8 percent), employees who agreed with the importance of employee promotion by 22 (71 percent) and employees who had a good labour productivity by 24 (77 percent). The research also showed that there was a significant association between the employment promotions with labour productivity. The test was also obtained from the OR value of 12,500 which means that respondents who expected and received employee promotions had good labour productivity as much as 12.5 times that of the respondents who did not expect and got an employee promotion. From the study, it could be concluded that the information had a strong influence on labour productivity. Employees who had hope of getting better employment promotion opportunities to result in labour productivity were 12 times better than employees who did not expect a promotion. The study advised policymakers to better organize the employment promotion mechanism to make it more equitable and proportional to the achievements.

Mohammad, Indra, and Abu (2013) carried out a study on the relationship between motivational factors and job performance of employees in Malaysian Service Industry. Developments in the service industry had heightened the need for motivating employees. The aim of the study was to have a better understanding of the factors of employee motivation and their association with job performance in Malaysian servicing organizations. The dependent variable in the study was job performance. The independent variables were motivational factors namely payment, job security, promotion, freedom, a friendly environment, and training. A correlation research design was used in the study. The survey method was used to collect data. The research tool was a structured questionnaire. A convenience sampling technique was used to select the respondents for the study. 
A total of 130 employees of service organizations constituted the sample. The results obtained from the study showed that among the motivational factors, two variables were found to be significant predictors of job performance. Training contributed 40.4 percent to job performance while promotion contributed an additional 3 percent. Finding of the research was that intrinsic motivational factors were considered more important compared to extrinsic motivational factors such as payment, job security, and friendly environment. Freedom an intrinsic variable, however, was not found to be significantly related to job performance.

Hatice (2013) examined the influence of intrinsic and extrinsic rewards on employee results: An empirical analysis was conducted in Turkish manufacturing industry in Afyon Kocatepe University. The study discussed in the article questions whether certain reward practices used by organizations were better than others when compared with the employee results based on TQM. Reward systems and TQM relevant literature were first examined. In the sample, which consisted of 217 businesses that operated in the Turkish manufacturing industry and applied TQM, intrinsic and extrinsic reward practices of firms on people results were analyzed. The results of the survey were analyzed through descriptive statistics, ANOVA and MANOVA. As the main finding of the research, it was determined that application level of intrinsic and extrinsic rewards in Turkish manufacturing industry was not high. It was identified that intrinsic rewards had a significant influence on employee results; however extrinsic rewards did not have significant control over employee results in Turkish manufacturing industry. The study highlighted the importance of the intrinsic reward system for implementing TQM.

Josephine (2015) carried out a research on non-financial reward and employee retention in private primary schools in Kenya (Kiambu County). Most researches undertaken had focused on the monetary aspects of reward. Little effort had been taken to understand the value of non-financial rewards. The objective of the research was to determine whether private schools in Kenya were utilizing non-financial rewards as a competitive benefit in retraining their employees. A survey was done on the heads and teachers of selected private schools to find out their perception of the use of different non-financial rewards in retaining their services in their institutions. The objectives of the study were achieved through conducting a survey on the employees of selected schools. The results that described the entire population was used. The main findings were that job flexibility was an important tool because it gave the employee some authority in their working hours. That gave them room to cater for any other eventualities that might arise in their life away from the office hence the job did not turn out to be a hindrance to their duties prompting them to serve the institution longer years. The findings under paternity leave were almost at a tie because the greater part of the respondents had gone through the stage of paternity leave and others had no intention of the same thereby finding it not relevant. That required an employer to gain knowledge of the employee well enough to ensure he or she offers benefits that were relevant to them. From the results of the research, non-financial rewards took dominance as a factor of employee retention. It was recommended that organizations review their reward practices to make sure alignment with the potential impact of changes in the macro environment and to make allowance for diverse requirements based on the demographic factors of their employees. 
INTERNATIONAL JOURNAL OF ACADEMIC RESEARCH IN BUSINESS AND SOCIAL SCIENCES

Vol. 8, No. 9, Sept. 2018, E-ISSN: 2222-6990 @ 2018 HRMARS

\section{Summary of Empirical Review}

The goal of motivating employees without money is to encourage employees to focus and engage in fulfillment of company objectives. Non-financial rewards are powerful tools in motivating employees and organizational performance, mainly in weak economic times. The goal of any reward system is for every employee to be engaged, and to carry his/her work with the best quality. A combination of financial and non-financial rewards can help improve staff morale, job satisfaction and enhance productivity. Motivation is the key to stimulating employee performance.

\section{Methodology}

The study was based on investigating the effect of non- financial rewards on staff productivity. The area of study was Shoprite located in Enugu. The firm was purposively selected because it had high strength and operated on high ethical standards. The study used the survey approach. The primary sources were a personal interview and the administration of questionnaire to the management and staff of the company. A population of 275 staff was used. The validity of the instrument was tested using content analysis and expert opinion, and the result was good. The reliability was tested using the Pearson correlation coefficient ( $r$ ). It gave a reliability coefficient of 0.78 which was also good. The hypotheses were tested using F-statistic (ANOVA) tool.

Data Presentation and Analysis

Table 4.1 Response on the relationship between medical benefits and level of absenteeism because of sick leave

\begin{tabular}{lllll}
\hline & Frequency & Percent & Valid Percent & $\begin{array}{l}\text { Cumulative } \\
\text { Percent }\end{array}$ \\
\hline Strongly Agree & 120 & 43.6 & 43.6 & 43.6 \\
Agree & 113 & 41.1 & 41.1 & 84.7 \\
Neutral & 5 & 1.8 & 1.8 & 86.5 \\
Disagree & 22 & 8.0 & 8.0 & 94.5 \\
Strongly Disagree & 15 & 5.5 & 5.5 & 100.0 \\
\hline Total & 275 & 100.0 & 100.0 & \\
\hline
\end{tabular}

Source: Field Survey, 2018

From the table 4.1, 120 respondents out of 275 representing 43.6 percent strongly agree, 113 respondents of 41.1 percent agree that there was a relationship between medical benefits and level of absenteeism because of sick leave, 5 respondents or 1.8 percent were neutral, 22 respondents representing 8.0 percent disagree while 15 respondents or 5.5 percent strongly disagree that there was a relationship between medical benefits and level of absenteeism because of sick leave. 
INTERNATIONAL JOURNAL OF ACADEMIC RESEARCH IN BUSINESS AND SOCIAL SCIENCES Vol. 8, No. 9, Sept. 2018, E-ISSN: 2222-6990 @ 2018 HRMARS

\begin{tabular}{|l|l|l|l|l|l|}
\hline \multicolumn{6}{|l|}{ Table 4.2: Response to the relationship between having relaxation areas and the volume of output } \\
\hline \multicolumn{2}{|l|}{} & Frequency & Percent & Valid Percent & $\begin{array}{l}\text { Cumulative } \\
\text { Percent }\end{array}$ \\
\hline \multirow{3}{*}{} & Strongly Agree & 143 & 52.0 & 52.0 & 52.0 \\
\cline { 2 - 6 } & 83 & 30.2 & 30.2 & 82.2 \\
\cline { 2 - 6 } & Neutral & 9 & 3.3 & 3.3 & 85.5 \\
\cline { 2 - 6 } & 23 & 8.4 & 8.4 & 93.8 \\
\hline & Strongly Disagree & 17 & 6.2 & 6.2 & 100.0 \\
\hline & Total & $\mathbf{2 7 5}$ & $\mathbf{1 0 0 . 0}$ & $\mathbf{1 0 0 . 0}$ & \\
\hline
\end{tabular}

\section{Source: Field Survey, 2018}

From the table 4.2, 143 of respondents out of 275 representing 52.0 percent strongly agree, 83 respondents of 30.2 percent agree that there is a relationship between having relaxation areas and an increase in the volume of output, 9 respondents or 3.3 percent were neutral, while 23 respondents representing 8.4 percent disagree, 17 respondents or 6.2 percent strongly disagree that there was a relationship between having relaxation areas and the volume of output.

\section{Test of Hypotheses}

i. The relationship between medical benefits and level of absenteeism because of sick leave

\section{Model Summary}

\begin{tabular}{|l|l|l|l|l|}
\hline Model & $R$ & R Square & $\begin{array}{l}\text { Adjusted R } \\
\text { Square }\end{array}$ & $\begin{array}{l}\text { Std. Error of } \\
\text { the Estimate }\end{array}$ \\
\hline 1 & $.946^{\mathrm{a}}$ & .894 & .893 & .24928 \\
\hline
\end{tabular}

a. Predictors: (Constant), HLRSA, HSFW.

\section{ANOVA $^{\mathrm{a}}$}

\begin{tabular}{|ll|l|l|l|l|l|}
\hline \multicolumn{2}{|l|}{ Model } & $\begin{array}{l}\text { Sum of } \\
\text { Squares }\end{array}$ & Df & Mean Square & F & Sig. \\
\hline \multirow{2}{*}{1} & Regression & 130.031 & 2 & 65.016 & 1046.270 & $.000^{\mathrm{b}}$ \\
& Residual & 15.411 & 248 & .062 & & \\
& Total & 145.442 & 250 & & & \\
\hline
\end{tabular}

a. Dependent Variable: RMBLASL

b. Predictors: (Constant), HLRSAR, HSFW 
INTERNATIONAL JOURNAL OF ACADEMIC RESEARCH IN BUSINESS AND SOCIAL SCIENCES Vol. 8, No. 9, Sept. 2018, E-ISSN: 2222-6990 @ 2018 HRMARS

Coefficients $^{\mathrm{a}}$

\begin{tabular}{|ll|l|l|l|l|l|}
\hline \multicolumn{2}{|l|}{ Model } & \multicolumn{2}{|l|}{ Unstandardized Coefficients } & $\begin{array}{l}\text { Standardized } \\
\text { Coefficients }\end{array}$ & T & Sig. \\
\cline { 3 - 6 } & & B & Std. Error & Beta & & \\
\hline \multirow{2}{*}{1} & (Constant) & -.630 & .131 & & 4.825 & .000 \\
& HLRSAR & .554 & .027 & .607 & 20.225 & .000 \\
& HSFW & .574 & .042 & .408 & 13.610 & .000 \\
\hline
\end{tabular}

a. Dependent Variable: RMBLASL

\section{Where \\ RMBLASL = Response to the relationship between medical benefits and level of absenteeism because of sick leave \\ HLRSAR = Response to the High loss of revenue due to sick absenteeism is reduced HSFW = Response on Health security ensures firms against their workers.}

\section{STATISTICAL CRITERIA \{FIRST ORDER TEST\}}

\section{COEFFICIENT OF MULTIPLE DETERMINANTS $\left\{R^{2}\right\}$}

The $R^{2}\{R$-Squared $\}$ which measures the overall goodness of fit of the entire regression, shows the value as .894 and adjusted to .893 . This means that $R^{2}$ accounts for 89.3 percent of approximately 89 percent. This indicates that the independent variables account for about 89 percent of the variation in the dependent variable. Which showed the goodness of fit.

\section{F-STATISTICS (ANOVA)}

The F-statistics is used to test for simultaneous significance of all the estimated parameters. The hypothesis is stated;

$H_{0}: \beta_{1}=\beta_{2}=\beta_{3}=\beta_{4}$

$H_{1}: \beta_{1} \neq \beta_{2} \neq \beta_{3} \neq \beta_{4}$

Level of significance: $\alpha$ at 5 percent

Degree of freedom: $\frac{K-1}{N-K}=\frac{3-1}{275-3}=(272,2)=2.7858$

\section{Decision Rule:}

If the F-calculated is greater than the F-tabulated $\{\mathrm{F}$-cal $>\mathrm{F}$-tab $\}$ reject the null hypothesis $\mathrm{H}_{0}$ that the overall estimate is not significant and if otherwise conclude that the overall estimate is statistically significant.

\section{Decision}

From the result, F-calculated $\{1046.270\}$ is greater than the F-tabulated $\{2.7858\}$, that is, F-cal $>$ Ftab. Hence, we reject the null hypothesis $\mathrm{HO}$ and accept the alternate hypothesis which means that the overall estimate has a good fit which also implies that our independent variables were simultaneously significant. We now conclude from the analysis there was a significant relationship between medical benefits and the level of absenteeism because of sick leaves 
INTERNATIONAL JOURNAL OF ACADEMIC RESEARCH IN BUSINESS AND SOCIAL SCIENCES Vol. 8, No. 9, Sept. 2018, E-ISSN: 2222-6990 (C) 2018 HRMARS

ii. The relationship between having relaxation areas and volume of output.

Regression

Model Summary

\begin{tabular}{|l|l|l|l|l|}
\hline Model & $R$ & R Square & $\begin{array}{l}\text { Adjusted R } \\
\text { Square }\end{array}$ & $\begin{array}{l}\text { Std. Error of } \\
\text { the Estimate }\end{array}$ \\
\hline 1 & $.968^{\mathrm{a}}$ & .937 & .936 & .22226 \\
\hline
\end{tabular}

a. Predictors: (Constant), HRAREW,TCSEWFE

ANOVA $^{\mathrm{a}}$

\begin{tabular}{|ll|l|l|l|l|l|}
\hline \multicolumn{2}{|l|}{ Model } & $\begin{array}{l}\text { Sum of } \\
\text { Squares }\end{array}$ & Df & Mean Square & F & Sig. \\
\hline \multirow{2}{*}{1} & Regression & 199.340 & 3 & 66.447 & 1345.096 & $.000^{\mathrm{b}}$ \\
& Residual & 13.387 & 271 & .049 & & \\
& Total & 212.727 & 274 & & & \\
\hline
\end{tabular}

a. Dependent Variable: RHRAVO,

b. Predictors: (Constant), HRAREW,TCSEWFE, TCRAJS

Coefficients $^{\mathrm{a}}$

\begin{tabular}{|c|c|c|c|c|c|c|}
\hline \multirow{2}{*}{\multicolumn{2}{|c|}{ Model }} & \multicolumn{2}{|c|}{ Unstandardized Coefficients } & \multirow{2}{*}{\begin{tabular}{|l} 
Standardized \\
Coefficients \\
Beta \\
\end{tabular}} & \multirow[t]{2}{*}{$\mathrm{T}$} & \multirow[t]{2}{*}{ Sig. } \\
\hline & & $B$ & Std. Error & & & \\
\hline \multirow{4}{*}{1} & (Constant) & .353 & .067 & & 5.310 & .000 \\
\hline & HRAREW & .013 & .029 & .014 & .445 & .657 \\
\hline & TCSEWFE & .573 & .041 & .640 & 13.825 & .000 \\
\hline & TCRAJS & .325 & & .330 & & .000 \\
\hline
\end{tabular}

a. Dependent Variable: RHRAVO

Where:

RHRVO = $\quad$ Response on the relationship between having relaxation areas and volume of output.

HRALEW $=$ Response on having relaxation areas level of work demand impacts on employees' work

TCSEWFE = Response on the costs of work stress appear impaired in employee well being and creates a friendly environment to work.

TCRAJS = Response on the company's relaxation area job security

STATISTICAL CRITERIA \{FIRST ORDER TEST\}

COEFFICIENT OF MULTIPLE DETERMINANTS $\left\{R^{2}\right\}$

The $R^{2}\{R$-Squared $\}$ which measures the overall goodness of fit of the entire regression, shows the value as .937 and adjusted to .937. This means that $R^{2}$ accounts for 93.7 percent approximately 94 
INTERNATIONAL JOURNAL OF ACADEMIC RESEARCH IN BUSINESS AND SOCIAL SCIENCES

Vol. 8, No. 9, Sept. 2018, E-ISSN: 2222-6990 @ 2018 HRMARS

percent. This indicates that the independent variables account for about $94 \%$ of the variation in the dependent variable. Which showed the goodness of fit.

\section{F-STATISTICS (ANOVA)}

The F-statistics is used to test for simultaneous significance of all the estimated parameters.

The hypothesis is stated;

$H_{0}: \beta_{1}=\beta_{2}=\beta_{3}=\beta_{4}$

$H_{1}: \beta_{1} \neq \beta_{2} \neq \beta_{3} \neq \beta_{4}$

Level of significance: $\alpha$ at $5 \%$

Degree of freedom: $\frac{N-1}{N-K}=\frac{4-1}{275-4}=(272,3)=2.7858$

\section{Decision Rule:}

If the $f$-calculated is greater than the f-tabulated $\{f$-cal $>f$-tab $\}$ reject the null hypothesis $\mathrm{HO}$ that the overall estimate is not significant and if otherwise conclude that the overall estimate is statistically significant.

\section{Decision}

From the result, F-calculated $\{1345.096\}$ is greater than the F-tabulated $\{2.7858\}$, that is, F-cal $>$ Ftab. Therefore, we reject the null hypothesis $\mathrm{HO}$ and accept Alternate hypothesis which means that the overall estimate has a good fit which also implies that our independent variables were simultaneously significant. We now conclude from the analysis that there was a significant relationship between having relaxation areas and volume of output.

\section{Discussion of Findings}

In the literature review, Thomas (2013) stated that there are reasons for high rates of absenteeism: an abnormal amount of illness, and misuse of the system by workers who call in sick when they're actually perfectly healthy. Causes for one or both of these may be as follows, definite physical or mental illness, an unwholesome lifestyle, problems in the workplace, causing avoidance or stressrelated illness, lack of understanding of sick leave policies. In line with this, the result of hypotheses one proved the above assertion since, from the result, F-calculated $\{1046.270\}$ was greater than the F-tabulated $\{2.7858\}$, that is, F-cal > F-tab. Therefore, we reject the null hypothesis $\mathrm{H}_{0}$ and accept alternate hypothesis which means that the overall estimate had a good fit which also implies that the independent variables were simultaneously significant. We now conclude from the analysis that there was a significant relationship between medical benefits and level of absenteeism because of sick leaves. Therefore, there is a significant positive relationship between medical benefits and level of absenteeism because of sick leave.

In the analysis of hypothesis two, F-calculated $\{1345.096\}$ is greater than the F-tabulated $\{2.7858\}$, that is, F-cal > F-tab. Hence, we reject the null hypothesis $\left\{\mathrm{H}_{0}\right\}$ and accept alternate hypothesis which means that the overall estimate had a good fit which also implied that the independent variables were simultaneously significant. We conclude that there was a significant positive relationship between having relaxation areas and the level of output. In support of this, Raheem (2012), indicated 
INTERNATIONAL JOURNAL OF ACADEMIC RESEARCH IN BUSINESS AND SOCIAL SCIENCES

Vol. 8, No. 9, Sept. 2018, E-ISSN: 2222-6990 (C) 2018 HRMARS

that employees exposed to stressful work conditions experience strain and suffer from poor wellbeing, which in turn has harmful effects on job performance and increases sickness absences.

\section{Summary of Findings}

The study found the following:

i. There was a significant positive relationship between medical benefits and level of absenteeism because of sick leave $F(95, n=275)=1046.270, p<0.05$.

ii. There was a significant positive relationship between having relaxation areas and level of output $F(95, n=275)=1345.096, p<0.05$.

\section{Conclusion}

Based on the findings of the study, non -financial reward and staff productivity impacted on the industrial harmony, job productivity, commitment to task and efficiency. With sustainable human resources development programme, organizations achieve successful changes in the organization. Effective non-financial rewards would encourage hard work, self reliance and improved productivity of the labour force. Employees' desire to contribute increases because of the recognition of their contribution through an efficient performance, in this way, it stimulates the average and low performers to follow the high performers in expectation of rewards. It also communicates to the employees that the organization was authentically concerned about their development; as a result employee commitment and motivation increase.

\section{Recommendations}

Based on the findings of the study, the following recommendations were made on the effect of non -financial rewards on staff productivity:

1. Organizations should offer proper medical incentive through the provision of health insurance facility to its employees to keep them motivated.

2. There should be well prepared programmes for growth and development based on a wellarticulated national empowerment and development strategy to provide relaxation areas in the workplace.

\section{References}

Armstrong, M., \& Brown, D. (2012). Strategic reward: making it happen. USA: Kogan Page Limited.

Arnolds, C., \& Venter, D. (2017). The strategic importance of motivational rewards for lower-level employees in the manufacturing and retailing industries. South African Journal of Industrial Psychology, 33 (3), 15-23.

B.M.T. (2008). Mixing cash and noncash rewards. workforce management, 87 (15).

Bartol, K., \& Srivastava, A. (2002). Encouraging knowledge sharing: the role of organizational reward systems. Journal of Leadership \& Organisational Stidies, 9 (1), 64-76.

Bootzin, R., Loftus, E., Zajonc, R., Hall, E. (1983). $5^{\text {th }}$ ed Psychology today: an introduction. New York: Random House.

Eboh, E. F., (2008). Management theory: models for decision making. Computer Villa Publishers Ltd. 
INTERNATIONAL JOURNAL OF ACADEMIC RESEARCH IN BUSINESS AND SOCIAL SCIENCES

Vol. 8, No. 9, Sept. 2018, E-ISSN: 2222-6990 @ 2018 HRMARS

Ezewuzie, C. G. (2008). Effect of motivation on organizational performance: A study of selected Banks in Enugu State. University of Nigeria, Enugu Campus unpublished thesis.

Hatice Ö. (2012). The influence of intrinsic and extrinsic rewards on employee results: an empirical analysis in turkish manufacturing industry. Business and Economics Research Journal 3(3),

Herzberg, F. (1966). Work and the nature of man. Cleveland: World Publishing Co.

Herzberg, F. (1987). One more time - how do you motivate employees? Harvard Business Review, 65 (5), 109-120.

Hijazi, S., Anwar, A., \& Mehbood, S. (2007). Impact of non-financial rewards on employee motivation. the business review, 7 (2), 272-277.

Josephine W. N., (2015). Non-financial reward and employee retention in private primary schools in Kenya (Kiambu County)

Lawler, E. (1996). Team, pay and business strategies: finding the best mix to achieve competitive advantage. American Compensation Association Journal, 12-24.

Mahaney, R., \& Lederer. (2006). The effect of intrinsic and extrinsic rewards for developers on information systems project success. Project Management Journal, 37 (4), 42-54.

Maslow, A.H. (1954). A Theory of human motivation. Psychological Review, 50, 370-396.

Maslow, A.H. (1968). Toward a psychology of being. (2 ${ }^{\text {nd }}$ ed.). New York: Van Nostrand Reinhold.

McArthur, D. (2009). The reward challenges facing south African business from a manager's perspective. MBA. Thesis,. Johannesburg: Gordon Institue of Business Science.

McGregor, D.M. (1957). Proceedings of the Fifth Anniversary Convocation of the School of Industrial Management, The Human Side of Enterprise. Massachusetts Institute of Technology.

Mohammad, S. A., Indra, D. S. and Abu B. A. (2013). Relationship between motivational factors and job performance of employees in Malaysian Service Industry. Canadian Center of Science and Education.

Scott T., (2014). The Importance of Non-financial rewards for the organization. StudioD.

Syukra, A., (2014). The Relationship between training, compensation and employment promotion with labor productivity employees in public health centre (Puskesmas) of Bukittinggi-West Sumatera, Indonesia. Global Journal of Biology, Agriculture and Health Sciences 3(2).44-48

Tay, L., Diener, E. (2011). Needs and subjective well-being around the world. Journal of Personality and Social Psychology, 101(2).

Thomas, K. (2009, Nov/Dec). The Four Intrinsic Rewards that Drive Employee Engagement. Ivey Business Journal Online.

Vroom, V. (1964). Work and Motivation. New York: Jon Wiley \& Sons.

World at Work. (2007). The WorldatWork Handbook of Compensation, Benefits and Total Rewards. Hoboken, New Jersey: John Wiley and Sons, Inc.

Zingheim, P., \& Schuster, J. (2007). High performance pay. USA: World at Work Press.

Armstrong, M., \& Brown, D. (2006). Strategic reward: making it happen. USA: Kogan Page Limited.

Business Dictionary (2018) Non-monetary reward Retrieved

from: http://www.businessdictionary.com/definition/non-monetary-reward.htm/

Abramovitz, M. (2016). "Resource and output trends in the united states since 1870". American Economic Review. 46 (2): 5-23. 